\title{
STUDI KUALITAS BAKTERIOLOGIS AIR BERSIH DI KAPAL PENUMPANG PELNI DAN NON PELNI DI PELABUHAN NUSANTARA PAREPARE Fiatri Husain ${ }^{1}$ dan La Taha ${ }^{2}$
}

1.2 Jurusan Kesehatan Lingkungan Poltekkes Kemenkes Makassar fiatrihusain@gmail.com

\begin{abstract}
Water is the basic right of every living being because on earth all beings rely on the water without human beings. Approximately $70-80 \%$ of the bodyweight of a human body is water-filled. Therefore water is a basic necessity and plays an important role in the survival of life. Therefore, every ship that docked at the port checked the quality of bacteriologically clean water including the sanitary section of the ship. The aim of this study to get an Overview of Bacteriological Quality of Clean Water Pelni and Non-Pelni Passenger Vessels at the Port of Nusantara Parepare. This research type is a descriptive observational that is examining to know the existence of bacterium of MPN Coliform and Escherichia coli on Clean Water. The number of samples in this study is all 2 pieces of the ship and not pelni as many as 6 units of ships. Results research has been done that 2 Pelni vessels qualify E.coli even though 1 pelni vessel (lambelu) is found on the MPN Coliform examination results below the threshold. While 6 Non-Pelni vessels there are 3 positive MPN Coliform, 3 Ship negative MPN Coliform and on examination E.coli there are 5 vessels negative E.coli and 1 positive ship E.coli. The conclusion of this research that has been done there are 2 qualified Pelni vessels and non-relaxing ship 5 eligible and 1 NonPelni ship does not meet the requirement of KM Queen Soya according to Permenkes. 32 The year 2017. So then it expected workers to pay attention to cleanliness aboard ship on the part of sanitation, especially in the water supply.
\end{abstract}

Keywords: Clean Water, Bacteriology, Pelni Ship and Non-Pelni

\section{ABSTRAK}

Air merupakan hak dasar bagi setiap makhluk hidup karena di bumi semua makhluk menggantungkan hidupnya pada air tanpa terkecuali manusia. Sekitar $70-80 \%$ dari berat badan tubuh manusia adalah mengandung air. Oleh karena itu air menjadi kebutuhan pokok dan berperan penting bagi kelangsungan kehidupan. Maka dari itu setiap kapal yang sandar di pelabuhan diperiksa kualitas bakteriologis air bersih yang termasuk bagian sanitasi kapal. Penelitian ini bertujuan untuk mendapatkan Gambaran Tentang Kualitas Bakteriologis Air Bersih di Kapal Penumpang Pelni dan Non Pelni di Pelabuhan Nusantara Parepare. Jenis penelitian ini observasional deskriptif yaitu melakukan pemeriksaan untuk mengetahui adanya bakteri MPN Coliform dan Eschericia Coli pada Air Bersih. Adapun jumlah sampel dalam penelitian ini seluruh kapal penumpang pelni sebanyak 2 buah kapal dan non pelni sebanyak 6 buah kapal. Hasil penelitian yang telah dilakukan bahwa 2 Kapal Pelni memenuhi syarat E.coli walaupun 1 kapal pelni (lambelu) ditemukan hasil pemeriksaan MPN Coliform masih dibawah ambang batas. Sedangkan 6 kapal Non Pelni terdapat 3 positif MPN Coliform, 3 Kapal negatif MPN Coliform dan pada pemeriksaan E.coli terdapat 5 kapal yang negatif E.coli dan 1 kapal positif E.coli. Kesimpulan dari penelitian ini yang telah dilakukan terdapat 2 kapal Pelni memenuhi syarat dan kapal Non Pelni 5 yang memenuhi syarat dan 1 kapal Non Pelni tidak memenuhi syarat yaitu KM Queen Soya sesuai Permenkes No. 32 Tahun 2017. Jadi diharapkan pekerja kapal untuk memperhatikan kebersihan kapal pada bagian sanitasinya khususnya pada air bersih.

Kata Kunci : Air Bersih, Bakteriologis, Kapal Pelni dan Non Pelni

\section{Pendahuluan}

Air merupakan sumber daya alam yang diperlukan untuk hajat hidup orang banyak, bahkan oleh semua makhluk hidup. Oleh karena itu, sumber daya air harus dilindungi agar tetap dapat dimanfaatkan dengan baik oleh manusia serta mahluk hidup yang lain (Effendi, 2003).

Akses terhadap air bersih dan sanitasi merupakan salah satu fondasi inti dari masyarakat yang sehat, sejahtera dan damai. Sistem air bersih dan sanitasi yang baik akan menghasilkan manfaat ekonomi, melindungi lingkungan hidup, dan vital bagi kesehatan manusia. Jenis sarana air bersih ada beberapa macam yaitu PAM, sumur gali, sumur pompa tangan dangkal dan sumur pompa tangan dalam, tempat penampungan air hujan, penampungan mata air, dan perpipaan. Sirkulasi air, pemanfaatan air, serta sifat-sifat air memungkinkan terjadinya pengaruh air terhadap kesehatan. Secara khusus, pengaruh air terhadap kesehatan dapat bersifat langsung maupun tidak langsung (Defi, 2012).

Bakteriologi adalah ilmu yang mempelajari tentang bakteri. Bakteri merupakan mikroba dengan dinding sel yang berfungsi melindungi protoplast. Protoplast terdiri dari membran sitoplasma yang memagari komponenkomponen dalam dan struktur lainnya, antara lain: ribosom dan kromosom yang ada didalamnya

Pelabuhan adalah tempat yang terdiri atas daratan dan/atau perairan dengan batas-batas tertentu sebagai tempat kegiatan pemerintahan dan kegiatan pengusahaan yang dipergunakan sebagai tempat kapal bersandar, naik turun penumpang, dan bongkar muat barang, berupa terminal dan tempat berlabuh kapal yang dilengkapi dengan fasilitas keselamatan dan keamanan pelayaran dan kegiatan penunjang pelabuhan serta sebagai tempat perpindahan intra-dan antarmoda transportasi (Peraturan 
Jurnal Sulolipu : Media Komunikasi Sivitas Akademika dan Masyarakat

Vol. 19 No.12019

e-issn : 2622-6960, p-issn : 0854-624X

Pemerintah Republik Indonesia No.61 Tahun 2009).

\section{Bahan dan Metode}

1. Lokasi dan Waktu Penelitian

a. Lokasi Penelitian

Lokasi pengambilan sampel yaitu, di Kapal Penumpang Pelni dan Non Pelni di Pelabuhan Nusantara Parepare.

b. Lokasi Pemeriksaan Sampel

Lokasi untuk melakukan pemeriksaan kualitas bakteriologis air bersih adalah di UPTD Laboratorium Lingkungan Hidup Parepare.

2. Waktu Penelitian

Waktu penelitian dibagi menjadi dua tahap, yaitu:

a. Tahap Persiapan yang meliputi pengumpulan data sekunder yang berlangsung pada bulan Desember 2017 - April 2018.

b. Tahap Pelaksanaan meliputi kegiatan penelitian yang berlangsung pada bulan April - Mei 2018.

3. Variabel Penelitian

a. Variabel Bebas

Merupakan variabel yang berpengaruh terhadap variabel terikat, dalam penelitian ini yaitu, MPN Coliform dan E.coli.

b. Variabel Terikat

Merupakan variabel yang dipengaruhi oleh variabel bebas, dalam penelitian ini yaitu, kualitas air bersih.

c. Variabel Penganggu.

Merupakan variabel yang mempengaruhi variabel bebas dan

4. Populasi dan Sampel terikat namun diteliti yaitu, $\mathrm{pH}$ dan suhu.

a. Populasi

Seluruh kapal penumpang Pelni sebanyak 2 buah kapal dan Non Pelni sebanyak 6 buah kapal di Pelabuhan Nusantara Parepare.

b. Sampel

Sampel yang diambil dalam penelitian ini adalah Total sampling yang ada di kapal penumpang Pelni dengan jumlah sampel sebanyak 2 buah kapal dan Non Pelni dengan jumlah sampel sebanyak 6 buah kapal. Adapun teknik pengambilan sampel air yaitu, cara observasional dengan pendekatan deskriptif dengan menggunakan lembar observasi dan uji laboratorium.

\section{Analisa Data}

Data dianalisa secara deskriptif yaitu dengan mengetahui hubungan kualitas air dengan pemeriksaan biologisnya. Data yang diperoleh kemudian di analisis menggunakan deskriptif.

\section{HASIL PENELITIAN}

Berdasarkan penelitian yang telah dilaksanakan terhadap kualitas air bersih yang berasal dari bak penampungan utama pelabuhan, 2 kapal Pelni dan 6 kapal Non Pelni yang diambil sebagai sampel air yaitu pada tanggal 15 Mei 2018 - 23 Mei 2018. Dilaksanakan di UPTD Laboratorium Lingkungan Hidup kota Parepare. Maka hasilnya dapat dilihat pada uraian-uraian berikut di bawah ini :

1. Hasil Pemeriksaan Laboratorium Terhadap Kualitas Bakteriologis Air Bersih Di Kapal Penumpang Pelni Di Pelabuhan Nusantara Parepare.

Kualitas air bersih dapat di ukur melalui pemeriksaan di Laboratorium berdasarkan persyaratan sesuai dengan Peraturan Menteri Kesehatan R.I NO.32 Tahun 2017 tentang syarat-syarat dan kualitas air. Sehingga dilakukan pemeriksaan kualitas bakteriologis air bersih dikapal penumpang Pelni di Pelabuhan Nusantara Parepare dengan pemeriksaan Parameter MPN Coliform dan E.coli yang dapat dilihat berdasarkan pada perhitungan tabel MPN dengan tes penegasan BGLB dan Ec.Medium (Lampiran) hasil Laboratorium di bawah ini :

\section{Tabel 1}

Kualitas Bakteriologis (MPN Coliform) Air Bersih Di Kapal Penumpang Pelni Pelabuhan Nusantara Parepare Tahun 2018

\begin{tabular}{|c|c|c|c|c|}
\hline $\begin{array}{l}\mathbf{N} \\
\mathbf{O}\end{array}$ & $\begin{array}{l}\text { Sampel/N } \\
\text { ama } \\
\text { Kapal }\end{array}$ & $\begin{array}{l}\text { Jadwal } \\
\text { Pengambilan }\end{array}$ & $\begin{array}{c}\text { Hasil } \\
\text { MPN } \\
\text { Colifor } \\
\text { m }\end{array}$ & $\begin{array}{l}\text { Keterang } \\
\text { an }\end{array}$ \\
\hline 1 & $\begin{array}{l}\text { Bak } \\
\text { Utama } \\
\text { Pelabuhan }\end{array}$ & $\begin{array}{l}\text { Selasa, } 15 / 5 / 20 \\
18 \text { pukul 8:50 } \\
\text { WITA }\end{array}$ & 0 & \multirow{3}{*}{$\begin{array}{l}\text { Memenuh } \\
\text { i syarat } \\
\text { sesuai } \\
\text { Peraturan } \\
\text { Menteri } \\
\text { Kesehata } \\
\text { n NO.32 } \\
\text { Tahun } \\
2017\end{array}$} \\
\hline 2 & $\begin{array}{l}\text { KM } \\
\text { Lambelu }\end{array}$ & $\begin{array}{l}\text { Selasa, } 15 / 5 / 20 \\
18 \text { pukul } 15: 15 \\
\text { WITA }\end{array}$ & 4 & \\
\hline 3 & $\begin{array}{l}\text { KM Bukit } \\
\text { Siguntang }\end{array}$ & $\begin{array}{l}\text { Kamis, } 17 / 5 / 20 \\
18 \text { pukul 16:30 } \\
\text { WITA }\end{array}$ & 0 & \\
\hline
\end{tabular}

Sumber : Data Primer 
Tabel 2

Kualitas Bakteriologis (E.coli) Air Bersih Di Kapal Penumpang Pelni Pelabuhan Nusantara Parepare Tahun 2018

\begin{tabular}{|c|c|c|c|c|}
\hline $\begin{array}{l}\mathbf{N} \\
\mathbf{O}\end{array}$ & $\begin{array}{c}\text { Sampel/ } \\
\text { Nama } \\
\text { Kapal }\end{array}$ & $\begin{array}{c}\text { Jadwal } \\
\text { Pengambila } \\
n\end{array}$ & $\begin{array}{l}\text { Hasil } \\
\text { E.coli }\end{array}$ & $\begin{array}{c}\text { Keterang } \\
\text { an }\end{array}$ \\
\hline 1 & $\begin{array}{l}\text { Bak } \\
\text { Utama } \\
\text { Pelabuha } \\
\mathrm{n}\end{array}$ & $\begin{array}{l}\text { Selasa, } 15 / 5 / \\
2018 \text { pukul } \\
\text { 8:50 WITA }\end{array}$ & $\underset{f}{\text { Negati }}$ & $\begin{array}{l}\text { Memenuhi } \\
\text { syarat } \\
\text { sesuai } \\
\text { Peraturan }\end{array}$ \\
\hline 2 & $\begin{array}{l}\text { KM } \\
\text { Lambelu }\end{array}$ & $\begin{array}{l}\text { Selasa, } 15 / 5 / \\
2018 \text { pukul } \\
15: 15 \text { WITA }\end{array}$ & $\underset{f}{\text { Negati }}$ & $\begin{array}{c}\text { Menteri } \\
\text { Kesehatan } \\
\text { NO.32 }\end{array}$ \\
\hline 3 & $\begin{array}{l}\text { KM Bukit } \\
\text { Siguntan } \\
\text { g }\end{array}$ & $\begin{array}{l}\text { Kamis, } 17 / 5 / \\
2018 \text { pukul } \\
\text { 16:30 WITA }\end{array}$ & $\underset{f}{\text { Negati }}$ & $\begin{array}{l}\text { Tahun } \\
2017\end{array}$ \\
\hline
\end{tabular}

Sumber : Data Primer

1. Hasil Pemeriksaan Laboratorium Terhadap Kualitas Bakteriologis Air Bersih di Kapal Penumpang Non Pelni Di Pelabuhan Nusantara Parepare.

Kualitas air bersih dapat di ukur melalui pemeriksaan di Laboratorium berdasarkan persyaratan sesuai dengan Peraturan Menteri Kesehatan R.I NO.32 Tahun 2017 tentang syarat-syarat dan kualitas air. Sehingga dilakukan pemeriksaan kualitas bakteriologis air bersih di kapal penumpang Non Pelni Pelabuhan Nusantara Parepare dengan pemeriksaan MPN Coliform dan E.coli yang dapat dilihat pada tabel di bawah ini:

Tabel 3

Kualitas Bakteriologis (MPN Coliform) Air Bersih Di Kapal Penumpang Non Pelni Pelabuhan Nusantara Parepare Tahun 2018

\begin{tabular}{|c|c|c|c|c|}
\hline No & $\begin{array}{l}\text { Sampel/ } \\
\text { Nama } \\
\text { Kapal }\end{array}$ & $\begin{array}{l}\text { Jadwal } \\
\text { Pengambila } \\
\mathrm{n}\end{array}$ & $\begin{array}{l}\text { Hasil } \\
\text { MPN } \\
\text { Colifor } \\
\text { m }\end{array}$ & $\begin{array}{l}\text { Keterang } \\
\text { an }\end{array}$ \\
\hline 1 & $\begin{array}{l}\text { KM } \\
\text { Queen } \\
\text { Soya }\end{array}$ & $\begin{array}{l}\text { Selasa, } 15 / 5 / 2 \\
018 \text { pukul } \\
9: 15 \text { WITA }\end{array}$ & 21 & \multirow{6}{*}{$\begin{array}{c}\text { Memenu } \\
\text { hi syarat } \\
\text { sesuai } \\
\text { Peratura } \\
\text { n Menteri } \\
\text { Kesehata } \\
\text { n NO.32 } \\
\text { Tahun } \\
2017\end{array}$} \\
\hline 2 & $\begin{array}{l}\text { KM } \\
\text { Pantokr } \\
\text { ator }\end{array}$ & $\begin{array}{l}\text { Kamis, } 17 / 5 / 2 \\
018 \text { pukul } \\
\text { 7:30 WITA }\end{array}$ & 0 & \\
\hline 3 & $\begin{array}{l}\text { KM } \\
\text { Adithya }\end{array}$ & $\begin{array}{l}\text { Jumat, } 18 / 5 / 2 \\
018 \text { pukul } \\
\text { 10:30 WITA }\end{array}$ & 10 & \\
\hline 4 & $\begin{array}{l}\text { KM } \\
\text { Thalia }\end{array}$ & $\begin{array}{l}\text { Jumat, } 18 / 5 / 2 \\
018 \text { pukul } \\
\text { 9:00 WITA }\end{array}$ & 0 & \\
\hline 5 & $\begin{array}{l}\text { KM } \\
\text { Kirana }\end{array}$ & $\begin{array}{l}\text { Minggu, } \\
20 / 5 / 2018 \\
\text { pukul 14:45 } \\
\text { WITA }\end{array}$ & 8 & \\
\hline 6 & $\begin{array}{l}\text { KM } \\
\text { Madani }\end{array}$ & $\begin{array}{l}\text { Rabu, } \\
\text { 23/5/2018 } \\
\text { pukul 14:15 } \\
\text { WITA }\end{array}$ & 0 & \\
\hline
\end{tabular}

Sumber : Data Primer
Tabel 4 Kualitas Bakteriologis (E.coli) Air Bersih Di Kapal Penumpang Non Pelni Pelabuhan Nusantara Parepare Tahun 2018

\begin{tabular}{|c|c|c|c|c|}
\hline $\begin{array}{l}\mathbf{N} \\
\mathbf{O}\end{array}$ & $\begin{array}{l}\text { Sampel } \\
\text { /Nama } \\
\text { Kapal }\end{array}$ & $\begin{array}{l}\text { Jadwal } \\
\text { Pengambilan }\end{array}$ & $\begin{array}{l}\text { Hasil } \\
\text { E.coli }\end{array}$ & $\begin{array}{c}\text { Keterang } \\
\text { an }\end{array}$ \\
\hline 1 & $\begin{array}{l}\text { KM } \\
\text { Queen } \\
\text { Soya }\end{array}$ & $\begin{array}{l}\text { Selasa, } 15 / 5 / 2 \\
018 \text { pukul 9:15 } \\
\text { WITA }\end{array}$ & Positif & \multirow{6}{*}{$\begin{array}{c}\text { Tidak } \\
\text { Memenuh } \\
\text { i syarat } \\
\text { sesuai } \\
\text { Peraturan } \\
\text { Menteri } \\
\text { Kesehata } \\
\text { n NO.32 } \\
\text { Tahun } \\
2017\end{array}$} \\
\hline 2 & $\begin{array}{l}\mathrm{KM} \\
\text { Pantokr } \\
\text { ator }\end{array}$ & $\begin{array}{l}\text { Kamis, } 17 / 5 / 20 \\
18 \text { pukul 7:30 } \\
\text { WITA }\end{array}$ & Negatif & \\
\hline 3 & $\begin{array}{l}\text { KM } \\
\text { Adithya }\end{array}$ & $\begin{array}{l}\text { Jumat, } 18 / 5 / 20 \\
18 \text { pukul } 10: 30 \\
\text { WITA }\end{array}$ & Negatif & \\
\hline 4 & $\begin{array}{l}\text { KM } \\
\text { Thalia }\end{array}$ & $\begin{array}{l}\text { Jumat, } 18 / 5 / 20 \\
18 \text { pukul 9:00 } \\
\text { WITA }\end{array}$ & Negatif & \\
\hline 5 & $\begin{array}{l}\text { KM } \\
\text { Kirana }\end{array}$ & $\begin{array}{l}\text { Minggu, } \\
20 / 5 / 2018 \\
\text { pukul 14:45 } \\
\text { WITA }\end{array}$ & Negatif & \\
\hline 6 & $\begin{array}{l}\text { KM } \\
\text { Madani }\end{array}$ & $\begin{array}{l}\text { Rabu, } \\
\text { 23/5/2018 } \\
\text { pukul 14:15 } \\
\text { WITA }\end{array}$ & Negatif & \\
\hline
\end{tabular}

Sumber : Data Primer

2. Hasil Observasi penyediaan air bersih di kapal penumpang

Air merupakan sumber daya alam yang diperlukan untuk hajat hidup orang banyak, bahkan oleh semua makhluk hidup. Suplai air bersih untuk terminal penumpang dilakukan pada saat ada penumpang begitu juga dengan transportasi laut kapal penumpang, khususnya baik pada saat kedatangan dan pemberangkatan kapal. Sehingga secara kuantitas, air bersih ini hanya dikhususkan untuk melayani penumpang saja. Dalam hal ini usaha penyediaan air bersih digunakan sebagai salah satu indikator usaha kesehatan yang dapat dilihat dari hasil pemeriksaan fisik penyediaan air bersih di kapal penumpang Pelni dan Non Pelni sebagai penunjang sesuai tabel dibawah ini: 
Tabel 5.5

Hasil Observasi Pemeriksaan Fisik

Penyediaan Air Bersih Di Kapal Penumpang

Pelni dan Non Pelni Pelabuhan Nusantara

Parepare Tahun 2018

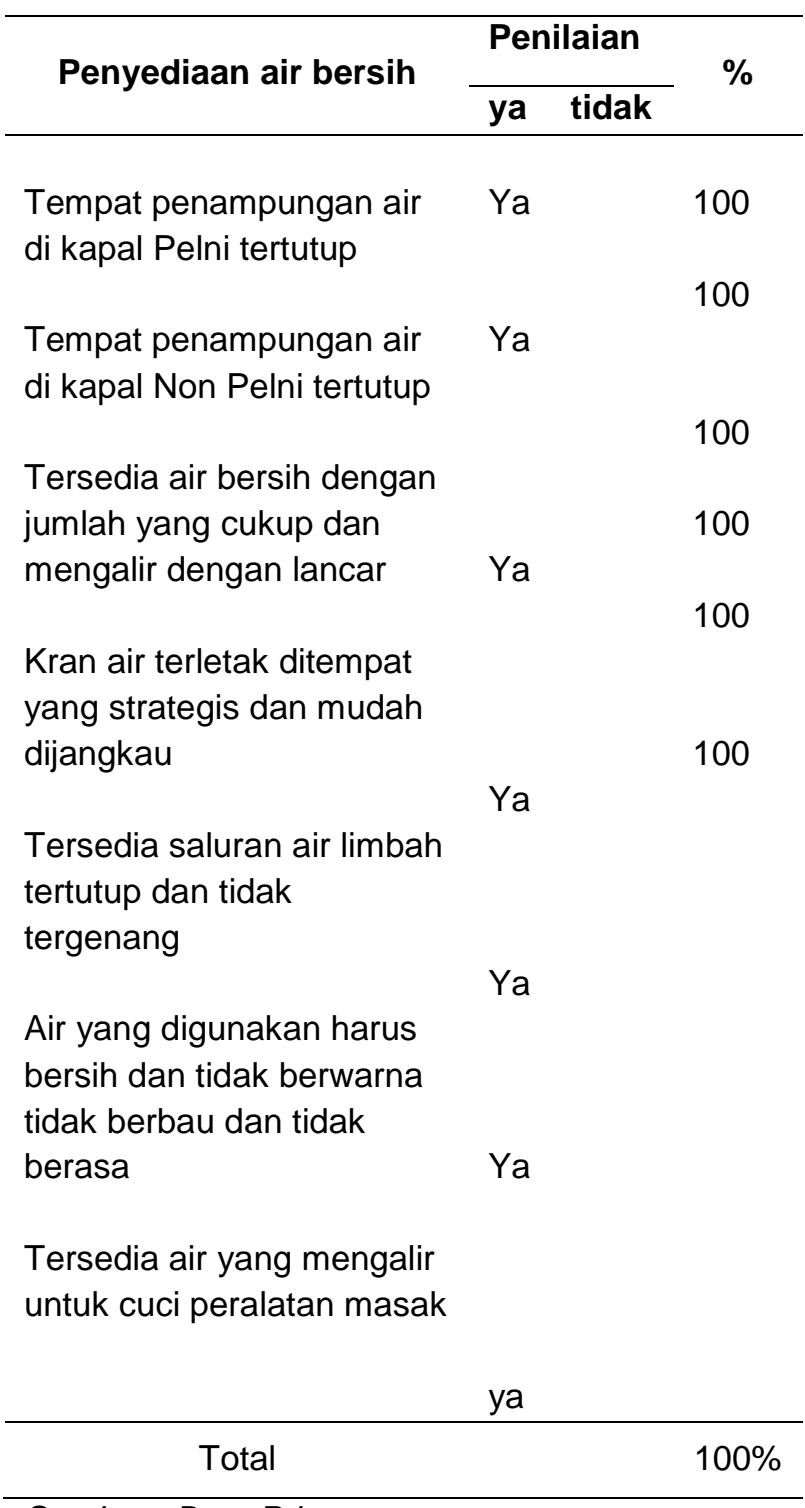

Sumber : Data Primer
Tabel 5.6

Hasil Observasi Pemeriksaan Fisik Hygiene Sanitasi Di Kapal Penumpang Pelni dan Non Pelni Pelabuhan Nusantara Parepare Tahun 2018

\begin{tabular}{|c|c|c|c|}
\hline \multirow{2}{*}{ Hygiene sanitasi } & \multicolumn{2}{|c|}{ Penilaian } & \multirow{2}{*}{$\%$} \\
\hline & ya & tidak & \\
\hline $\begin{array}{l}\text { Tersedia tempat } \\
\text { sampah di kapal } \\
\text { pelni }\end{array}$ & $\mathrm{Ya}$ & & 100 \\
\hline $\begin{array}{l}\text { Tersedia tempat } \\
\text { sampah di kapal } \\
\text { non pelni }\end{array}$ & Ya & & 100 \\
\hline $\begin{array}{l}\text { Kapal pelni } \\
\text { dibersihkan setiap } \\
\text { pengunjung turun } \\
\text { dari kapal }\end{array}$ & Ya & & 100 \\
\hline $\begin{array}{l}\text { Kapal non pelni } \\
\text { dibersihkan setiap } \\
\text { pengunjung turun } \\
\text { kapal pelni }\end{array}$ & $\mathrm{Ya}$ & & 100 \\
\hline Total & & & $100 \%$ \\
\hline \multicolumn{4}{|l|}{ Sumber : Data Primer } \\
\hline
\end{tabular}
observasi dan Laboratorium Mikrobiologi UPTD Lingkungan Hidup kualitas bakteriologis air bersih di kapal penumpang Pelni dan Non Pelni di Pelabuhan Nusantara Parepare bagian dapur Pelni memenuhi syarat $1 \mathrm{kapal}$ terdapat MPN Coliform KM Lambelu dan masih di bawah standar baku mutu Kesehatan Lingkungan, Non Pelni tidak memenuhi syarat 1 kapal terdapat MPN Coliform KM Queen Soya, 2 kapal terdapat MPN Coliform KM Adithya dan Km Kirana masih di bawah standar baku mutu Kesehatan Lingkungan, dan yang tidak memenuhi syarat atau teridentifikasi positif E.coli kapal Non Pelni KM Queen Soya.

1. Hasil Pemeriksaan Laboratorium Terhadap Kualitas Bakteriologis Air Bersih di Kapal Penumpang Pelni Di Pelabuhan Nusantara Parepare

Kualitas air bersih dapat di ukur melalui pemeriksaan di Laboratorium berdasarkan persyaratan sesuai dengan Peraturan Menteri Kesehatan R.I NO.32 Tahun 2017 tentang syarat-syarat dan kualitas air. Sehingga dilakukan pemeriksaan kualitas bakteriologis 
air bersih dikapal penumpang Pelni di Pelabuhan Nusantara Parepare dengan pemeriksaan Parameter MPN Coliform dan E.coli.

Coliform merupakan grup bakteri yang digunakan sebagai indikator adanya polusi kotoran dan kondisi yang tidak baik terhadap air, maupun bahan makanan. Kelompok bakteri Coliform dicirikan sebagai bakteri berbentuk batang, gram negatif, tidak membentuk spora, aerobik dan anaerobik fakultatif yang memfermentasi laktosa dengan menghasilkan asam dan gas dalam waktu 24 jam pada suhu $35^{\circ} \mathrm{C}$. Tentunya dengan keberadaan bakteri Coliform di dalam makanan/minuman menunjukkan kemungkinan adanya mikroba yang bersifat enteropatogenik dan atau toksigenik yang berbahaya bagi kesehatan (Edi Suriaman, 2017).

Berdasarkan Tabel 1 hasil pemeriksaan di laboratorium didapatkan hasil yaitu air yang berasal dari Bak Utama Pelabuhan diperoleh total MPN Coliform yaitu 0 , dan yang berasal dari 2 kapal Pelni yaitu KM Lambelu diperoleh total MPN Coliform 4 terdapat total bakteri walaupun masih dibawah ambang batas, KM Bukit Siguntang total Coliform 0 hasilnya memenuhi syarat sesuai dengan syarat kesehatan menurut Permenkes nomor 32 tahun 2017 tentang parameter biologi dalam standar baku mutu kesehatan lingkungan untuk media air untuk keperluan higiene sanitasi $50 \mathrm{CFU} / 100 \mathrm{ml}$.

Hasil penelitian ini sejalan dengan penelitian Novita Sekarwati (2016) hasil laboratorium pemeriksaan air bersih $\mathrm{Di} 8$ DAMIU dengan parameter Total Coliform diperoleh 1 DAMIU yaitu pada D8 yang memenuhi syarat, D8 diperoleh hasil 16,15/100 $\mathrm{ml}$ karena beberapa faktor fisik berdasarkan Ditjen P2PL Depkes RI tahun 2006 menyebutkan bahwa sumber air baku yang digunakan dari perusahaan air bersih swasta, selang air saat pemasukan kedalam tandon steril dan tandon air baku sudah di lakukan pembersihan atau pengurasan.

Berdasarkan Tabel 2 hasil pemeriksaan di laboratorium didapatkan hasil yaitu air yang berasal dari Bak Utama Pelabuhan diperoleh total E.coli yaitu negatif dan yang berasal dari 2 kapal Pelni yaitu KM Lambelu diperoleh total E.coli negatif. KM Bukit Siguntang E.coli negatif dan memenuhi syarat sesuai dengan syarat kesehatan menurut Permenkes nomor 32 tahun 2017 tentang parameter biologi dalam standar baku mutu kesehatan lingkungan untuk media air untuk keperluan higiene sanitasi 0CFU/ $100 \mathrm{ml}$.

Hasil penelitian ini sejalan dengan penelitian Novdahlia Febriyanti (2013) untuk jumlah bakteri $E$. coli yang memenuhi syarat dan penderita diarenya banyak ini karena selain bakteri penyebab diare bisa disebabkan juga karena virus, ataupun parasit sehingga penderita diare yang terjadi tidak seutuhnya karena bakteri E.coli itu sendiri melainkan juga karena faktor lain. Selain itu juga walaupun bakteri E.coli nya memenuhi syarat tapi jika tidak di perhatikan dalam menggunakan air yang sudah terkontaminasi maka akan mengakibatkan diare juga.

2. Hasil Pemeriksaan Laboratorium Terhadap Kualitas Bakteriologis Air Bersih Di Kapal Penumpang Non Pelni Di Pelabuhan Nusantara Parepare.

Kualitas air bersih dapat di ukur melalui pemeriksaan di Laboratorium berdasarkan persyaratan sesuai dengan Peraturan Menteri Kesehatan R.I NO.32 Tahun 2017 tentang syarat-syarat dan kualitas air. Sehingga dilakukan pemeriksaan kualitas bakteriologis air bersih dikapal penumpang Non Pelni Pelabuhan Nusantara Parepare dengan pemeriksaan MPN Coliform dan E.coli.

Escherichia coli merupakan bakteri Gram negative berbentuk batang pendek yang memiliki panjang sekitar $2 \mu \mathrm{m}$, diameter 0,7 $\mu \mathrm{m}$, lebar 0,4-0,7 $\mu \mathrm{m}$ dan bersifat anaerob fakultatif membentuk koloni bundar, cembung, dan halus dengan tepi nyata Escherichia coli adalah salah satu bakteri yang tergolong koliform dan hidup secara normal di dalam kotoran manusia maupun hewan, oleh karena itu disebut juga koliform fekal. Salah satu indikator adanya pencemaran air laut yaitu bakteri pencemar ,salah satunya adalah bakteri E.coli (Supardi dan sukamto,1999). 
Berdasarkan Tabel 3 hasil pemeriksaan di laboratorium didapatkan hasil yaitu yang berasal dari 6 kapal Non Pelni yaitu KM Queen Soya diperoleh total MPN Coliform 21. KM Pantokrator diperoleh total Coliform 0. KM Adithya diperoleh total Coliform 10. KM Thalia diperoleh total Coliform 0. KM Kirana diperoleh total Coliform 8. KM Madani diperoleh total Coliform 0 dan masih memenuhi syarat dan di bawah ambang batas sesuai dengan syarat kesehatan menurut Permenkes nomor 32 tahun 2017 tentang parameter biologi dalam standar baku mutu kesehatan lingkungan untuk media air untuk keperluan higiene sanitasi $50 \mathrm{CFU} / 100 \mathrm{ml}$.

Hasil penelitian ini sejalan dengan penelitian Hasria Alang (2014) Pada kualitas air PDAM untuk kecamatan Tamalate, Rappocini, Buakana dan Banta-bantaeng termasuk dalam Air bersih kelas A kategori baik karena mengandung total Coliform kurang dari 50 , sedangkan untuk kecamatan Panakkukang termasuk dalam Air bersih kelas $\mathrm{D}$ kategori amat buruk karena mengandung Coliform $1001-2400$.

Berdasarkan Tabel 4 hasil pemeriksaan di laboratorium didapatkan hasil yaitu yang berasal dari 6 kapal Non Pelni yaitu KM Queen Soya diperoleh E.coli Positif. KM Pantokrator diperoleh E.coli negatif . KM Adithya diperoleh E.coli negatif. KM Thalia diperoleh E.coli negatif. KM Kirana diperoleh E.coli negatif. KM Madani diperoleh E.coli negatif tidak memenuhi syarat sesuai dengan syarat kesehatan menurut Permenkes nomor 32 tahun 2017 tentang parameter biologi dalam standar baku mutu kesehatan lingkungan untuk media air untuk keperluan higiene sanitasi 0 CFU/ $100 \mathrm{ml}$.

Berdasarkan hasil penelitian Arlina Hardianti pada tahun 2015 kualitas bakteriologis (MPN Coliform) air bersih di kapal penumpang pelni Soekarno-Hatta Makassar, hasil pemeriksaan di laboratorium didapatkan hasil yaitu air yang berasal dari pelabuhan diperoleh total MPN Coliform yaitu 0 dan yang berasal dari 5 kapal yaitu KM. Labobar diperoleh total MPN Coliform mencapai >2400. KM. Bukit Siguntang diperoleh total MPN Coliform 9. KM. Kalimutu diperoleh total MPN Coliform 21. KM. Lambelu diperoleh total MPN Coliform 43, dan KM. Tunang Kabila diperoleh total MPN Coliform 9. Artinya air yang berasal dari pelabuhan tidak terdapat bakteri Coliform. Adapun hasil pemeriksaan kualitas bakteriologis (E.coli) air bersih di kapal penumpang Soekarno-Hatta Makkassar, hasil pemeriksaan di Laboratorium didapatkan hasil yaitu air yang berasal dari pelabuhan diperoleh total E.coli Negatif, dan yang berasal dari 5 kapal KM. Labobar diperoleh E.coli Negatif. KM. Bukit Siguntang diperoleh E.coli Negatif. KM. Kalimutu diperoleh E.coli positif. KM. Lambelu diperoleh E.coli Negatif dan KM Tunang Kabila diperoleh E.coli Positif.

Hal ini disebabkan karena pada air sampel yang diambil pada saat kedatangan kapal sehingga air yang ada di pelabuhan Nusantara Parepare, tetapi ada air yang berasal dari pelabuhan-pelabuhan yang kapal singgahi, sehingga air yang diperiksa belum tentu air yang berasal dari pelabuhan lain tidak diketahui sumber airnya. Kapal yang singgah di pelabuhan Nusantara Parepare tetap harus mengisi air walaupun air yang ada pada bak penampungan kapal belum habis, agar pada saat di perjalanan kapal tidak kehabisan air. Suplai air bersih khusus untuk terminal penumpang dilakukan pada saat-saat ada penumpang, baik pada saat kedatangan atau pemberangkatan. Selain itu kemungkinan diakibatkan pada saat dilakukan pengisian air bersih. Air bersih disalurkan dengan selang dan berjalan dengan baik, tetapi selang yang digunakan tidak terjamin kebersihannya sehingga hal ini dapat juga menjadi salah satu faktor terdapat bakteri coliform.

Pada bak penampungan kapal dan hydran/kran air yang tidak selalu dibersihkan tetapi hanya dalam waktu 6 bulan sekali dilakukan pembersihan sehingga tidak terjamin kebersihannya. Bakteri golongan coliform adalah indikator kualitas air. Makin sedikit kandungan coliform artinya kualitas air makin baik. Karena air yang tidak memenuhi syarat persyaratan kesehatan dapat menimbulkan bahaya-bahaya seperti meluasnya wabah penyakit terutama 
disebabkan oleh bakteri-bakteri patogen yang berasal dari saluran pencernaan baik saluran pencernaan manusia maupun saluran pencernaan hewan. Bakteri ini dapat tumbuh baik pada suhu antara $8^{\circ} \mathrm{C}-46^{\circ} \mathrm{C}$, dengan suhu optimum dibawah temperature $37^{\circ} \mathrm{C}$. Hal ini yang dapat mempengaruhi kualitas air bersih. Bakteri ini berada dibawah temperature minimum atau sedikit diatas temperature maksimum tidak segera mati, melainkan berada dalam keadaan lingkungan tertentu, disamping itu, Escherichia coli dapat tumbuh pada $\mathrm{pH}$ optimum berkisar 7,2 - 7,6. Sehingga inilah yang menjadi salah satu faktor adanya bakteri Escherichia coli pada air bersih di kapal bagian dapur.

Air yang didistribusi dari bak penampungan kapal dialirkan kebagian dapur menggunakan pipa-pipa yang tidak terjamin kebersihannya, serta dari pengamatan dapat dilihat bahwa ada kapal yang kondisi sanitasi pada bagian dapurnya terdapat serangga. Air sangat mudah menjadi kotor karena air merupakan zat yang bersifat sangat mudah larut sehingga dengan keadaan demikian lebih memungkinkan air tersebut mengandung bakteri yang patogen dalam jumlah yang besar. Pengaruh air sangat besar dalam penularan bibit penyakit. Besarnya pengaruh air dalam penularan tergantung dari kadar air itu sendiri. Karena penyakitpenyakit menular itu biasanya mudah tersebar melalui air disamping dengan cara lain, maka penetapan kualitas air dari sudut kesehatan dilakukan dengan pemeriksaan bakteri-bakteri patogen yang terdapat di dalam air tersebut, tetapi untuk menentukan ada tidaknya bakteri patogen dalam air sangatlah sulit dan biasanya jumlah bakteri patogen akan sangat sedikit, oleh karena bakteri patogen itu tadi akan segera mati oleh keadaan yang tidak menguntungkan bagi kehidupannya atau tidak tahan hidup lebih lama terhadap lingkungan yang tidak sesuai dengan kehidupannya.

Berdasarkan penelitian Laodi pada tahun 2012 analisis sistem supplay air bersih untuk kebutuhan transportasi laut kapal penumpang di pelabuhan Nusantara Parepare, Aspek kualitas air (bau, rasa dan warna) dari hasil respon penumpang di kapal terhadap kinerja PDAM sudah mencukupi. Untuk kontinuitas dan kualitas aliran air, para penumpang mengharapkan perlu adanya peningkatan kualitas pemeriksaan air bersih dan sanitasi lingkungan kapal dari segi fisik, biologi, dan kimia. Hasria Alang (2014)

Sedangkan hasil pemeriksaan Menurut kantor kesehatan pelabuhan kelas I Makassar (Wilayah kerja kesehatan pelabuhan Nusantara Parepare) tahun 2015 yang melakukan pemeriksaan kualitas air bersih setiap bulan dilakukan dengan cara pengambilan dan pemeriksaan sampel air yang bersumber dari reservoir tempat penampungan untuk kebutuhan air bersih di kapal yang dikelola oleh PT. Pelindo yang bersumber dari air PDAM, menunjukkan bahwa jumlah pemeriksaan sampel tahun 2015 sebanyak 24 sampel dengan hasil kualitas parameter fisik, ditemukan 24 memenuhi syarat, parameter kimia, dan bakteriologis satu sampel diperiksa dengan hasil memenuhi syarat. Untuk pengawasan air bersih dilakukan pemeriksaan secara teratur dan periodik setiap bulan untuk pemeriksaan fisik sedangkan untuk tahun 2015 pemeriksaan kimia dan bakteriologis dilakukan pada bulan hanya pada bulan Desember karena masih belum tersedianya alat Laboratorium lapangan.

\section{Hasil Observasi penyediaan air bersih di kapal penumpang}

Air merupakan sumber daya alam yang diperlukan untuk hajat hidup orang banyak, bahkan oleh semua makhluk hidup. Suplai air bersih untuk terminal penumpang dilakukan pada saat ada penumpang begitu juga dengan transportasi laut kapal penumpang, khususnya baik pada saat kedatangan dan pemberangkatan kapal. Sehingga secara kuantitas, air bersih ini hanya dikhususkan untuk melayani penumpang saja. Dalam hal ini usaha penyediaan air bersih digunakan sebagai salah satu indikator usaha kesehatan yang dapat dilihat dari hasil pemeriksaan fisik penyediaan air bersih di kapal penumpang Pelni dan Non Pelni sebagai penunjang.

Berdasarkan tabel 5 hasil observasi pemeriksaan fisik penyediaan air bersih di 
kapal Penumpang Pelni dan Non Pelni Nusantara Parepare. Semua Penampungan air di kapal Pelni tertutup, tempat penampungan air di kapal Non Pelni juga tertutup, tersedia air bersih dengan jumlah yang cukup dan mengalir dengan lancar, kran air terletak di tempat yang strategis dan terjangkau, tersedia saluran air limbah tertutup dan tidak tergenang, air yang digunakan harus bersih dan tidak berwarna tidak berbau dan tidak berasa, tersedia air yang mengalir untuk cuci peralatan semua memenuhi syarat $100 \%$ pada kapal Pelni dan Non Pelni.

Berdasarkan tabel 6 hasil observasi pemeriksaan fisik Hygiene Sanitasi di kapal Penumpang Pelni dan Non Pelni Nusantara Parepare. Tersedia tempat sampah di kapal Pelni, tersedia juga tempat sampah di kapal Non Pelni, Kapal Pelni dibersihkan setiap pengunjung turun dari kapal, Kapal Non Pelni dibersihkan setiap pengunjung turun kapal Pelni semua memenuhi syarat $100 \%$ pada kapal Pelni dan Non Pelni.

Pada penyediaan air bersih 8 kapal penumpang di antaranya Pelni dan Non Pelni di Pelabuhan Nusantara Parepare. Sumber air yang digunakan di kapal yaitu PDAM sesuai dengan induknya semua memenuhi persyaratan $100 \%$ pada kapal Pelni dan Non Pelni.

Hal ini Air PDAM yang di tampung di Bak Utama Pelabuhan Nusantara Parepare, sumber air permukaan dalam hal ini air sungai dari Salokarajae dan Jawi-jawi yang ditampung dan telah mengalami proses penyaringan dan pengolahan di Lasiming Parepare yang selanjutnya di salurkan melalui pipa distribusi.

Proses penyaluran air bersih yang ada di pelabuhan Nusantara Parepare yaitu bak penampungan utama berasal dari pelabuhan dialirkan melalui pipa besar masuk ke dermaga, kran besar yang ada di dermaga tersebut di putar dan disalurkan lagi melalui selang dan air yang dialirkan masuk ke kapal menuju bak penampungan yang ada di kapal tersebut. Hal tersebut proses kualitas penyaluran air bersih dan bak penampungan perlu di perhatikan dengan baik agar tidak terdapat mikroorganisme atau bakteri pathogen.

Pada hasil kuantitas air bersih kapal penumpang di antaranya Pelni dan Non Pelni di Pelabuhan Nusantara Parepare. Masih tersedia air yang cukup ketika saat sedang pengisian ke bak penampungan yang ada dan semua memenuhi persyaratan $100 \%$ pada kapal Pelni dan Non Pelni. Hal ini dikarenakan pada kapal Pelni pengisian air ke kapal tersebut sebanyak 80-100 kubik/jam ukuran selangnya 3 inch, dengan kapasitas 1000 rpm. Dan pada kapal Non Pelni pengisian air ke kapal tersebut sebanyak 4050 kubik/jam ukuran selangnya 2 inch, dengan kapasitas $600 \mathrm{rpm}$. Air bersih yang ada di kapal tersebut digunakan untuk mandi dan memasak semua kapal Pelni dan Non Pelni menggunakan air yang telah tersedia.

Perbandingan antara kapal Pelni dan Non Pelni, kapal Pelni yaitu KM Lambelu dan KM Bukit siguntang masih memenuhi syarat walaupun terdapat bakteri MPN coliform pada KM Lambelu terdapat 4 bakteri dan masih di bawah ambang batas yang sesuai dengan syarat kesehatan menurut Permenkes nomor 32 tahun 2017 tentang parameter biologi dalam standar baku mutu kesehatan lingkungan untuk media air untuk keperluan higiene sanitasi 50CFU/ 100ml, dan pada parameter pemeriksaan E.coli negatif. Sedangkan kapal Non Pelni yaitu KM Queen Soya, KM Pantokrator, KM Adithya, KM Thalia, KM Kirana, dan KM Madani memenuhi syarat walaupun terdapat sedikit bakteri KM Queen Soya MPN coliform 21, KM Adithya MPN coliform 10, KM Kirana MPN coliform 8 masih di bawah ambang batas yang sesuai dengan syarat kesehatan menurut Permenkes nomor 32 tahun 2017 tentang parameter biologi dalam standar baku mutu kesehatan lingkungan untuk media air untuk keperluan higiene sanitasi 50CFU/100ml, dan pada parameter pemeriksaan KM Queen Soya yang teridentifikasi positif Escherichia coli 21 tidak memenuhi syarat kesehatan menurut Permenkes nomor 32 tahun 2017 tentang parameter biologi dalam standar baku mutu kesehatan lingkungan untuk media air untuk keperluan higiene sanitasi $0 \mathrm{CFU} / 100 \mathrm{ml}$. 
Hal ini dikarenakan penyebab E.coli yaitu jenis bakteri coliform tinja biasanya ditemukan di usus hewan dan manusia. E. coli adalah singkatan dari Escherichia coli. Bakteri E-coli dalam air berasal dari pencemaran atau kontaminasi dari kotoran hewan dan manusia. Kotoran dapat berisi banyak jenis organisme penyebab penyakit.

Kapal KM Queen Soya dikatakan Positif pada pemeriksaan kualitas bakteriologis (E.coli) pada air bersih di kapal dikarenakan adanya pencemaran tinja yang ditemukan oleh usus hewan atau manusia, ini disebabkan karena tempat pembuangan tinja atau wc yang ada di kapal tersebut jaraknya dekat dengan dapur \pm 5 meter sehingga dapat terkontaminasi E.coli pada air kran yang ada di dapur kapal, kemungkinan pada saat kontak langsung dari orang ke orang pekerja kapal yang sudah tercemar oleh bakteri E.coli pada saat dari buang air besar atau kecil kemudian pergi keruang dapur dan mencuci makanan yang akan sedang dimasak, memutar kran air dan menyentuh mulut kran air tersebut maka akan tercemar oleh bakteri E.coli. Tercemarnya air yang ada di kapal juga bisa di sebabkan pada saat pencucian daging yang kurang hygiene apabila daging tersebut terdapat bakteri E.coli.

Pada saat pengambilan sampel kapal KM Queen Soya tersebut kapal baru saja tiba atau sandar di pelabuhan sehingga pada saat wawancara dan sedang mengisi lembar kuesioner dan observasi pekerja kapal yang ada di bagian dapur mengatakan bahwa air yang sedang di tampung di bak penampungan kapal, airnya masih dari daerah Nunukan bukan air yang di tampung di pelabuhan Parepare karena belum mengisi tangkinya, dan air daerah Nunukan yang diambil memang dalam keadaan keruh tapi tidak berasa, ini disebabkan faktor adanya bakteri E.coli dalam air. Keadaan dalam kapal tersebut memang kurang bersih sanitasi dapurnya kurang hygiene, kran airnya ada karatannya.

Pada observasi fisik semuanya memenuhi syarat penampungan air di kapal Pelni tertutup, tempat penampungan air di kapal Non Pelni juga tertutup, kran air mudah di jangkau, tersedia air yang mengalir untuk mencuci peralatan masak, tersedianya tempat sampah di kapal Pelni maupun Non Pelni, kapal dibersihkan saat pengunjung turun dari kapal. Di karenakan kapal sedang sandar, dan tidak terjamin apabila kapal sedang berlayar atau berlabuh pelabuhan lain, kemungkinan penampungan air tidak tertutup atau konsumen pengguna air kapal tidak hygienes, sampah-sampah yang di tampung bisa juga memberi pengaruh terhadap penampungan air di atas kapal sehingga terkontaminasi dengan bakteri coliform dan E.coli. Jadi perbandingan antara kapal Pelni dan Non Pelni dominan Pelni lebih baik di bandingkan dengan Non Pelni dari segi kualitas bakteriologis air bersih.

\section{Keterbatasan Penelitian}

1. Pada saat pengambilan sampel hanya saat kapal tiba atau sandar, tidak pada saat sementara berlabuh.

2. Pemeriksaan dilakukan hanya pada kualitas bakteriologisnya saja, tidak dengan fisik, kimia, sanitasi kapal, dan vektor yang ada di kapal tersebut.

\section{KESIMPULAN DAN SARAN}

\section{Kesimpulan}

Berdasarkan Hasil dan Pembahasan dapat disimpulkan sebagai berikut :

a. Pemeriksaan MPN coliform pada 2 sampel kapal Pelni memenuhi syarat, dan pemeriksaan E.coli pada 2 sampel kapal pelni juga memenuhi syarat.

b. Pemeriksaan MPN coliform pada 5 sampel kapal Non Pelni memenuhi syarat, Sedangkan Pemeriksaan E.coli 1 sampel kapal Non Pelni tidak memenuhi syarat yaitu kapal KM Queen Soya.

\section{Saran}

Berdasarkan hasil kesimpulan diatas, maka penulis menyarankan sebagai berikut :

a. Diharapkan kepada pekerja kapal untuk selalu memperhatikan kebersihan di kapal pada bagian sanitasinya, khusunya pada bagian pengisian airnya agar kualitasnya baik.

b. Bagi Institusi agar kiranya skripsi ini dapat digunakan dalam proses pembelajaran serta sebagai sumber referensi. 
Jurnal Sulolipu : Media Komunikasi Sivitas Akademika dan Masyarakat

Vol. 19 No.12019

e-issn : 2622-6960, p-issn : 0854-624X

\section{DAFTAR PUSTAKA}

Arlina Hardianti. 2015. Studi Kualitas Air Bersih di Kapal Penumpang Pelabuhan Soekarno-Hatta Makassar. Makassar Program Diploma III Jurusan Kesehatan Lingkungan Politeknik Kesehatan Makassar. (KTI tidak diterbitkan).

Bagus Prahutdi. 2012. Persyaratan Pelabuhan. (online). http://www.persyaratan\%20pelabuhan\%20_\%20sastra\%20sipil\%20indonesia.htm/. Diakses 12 Desember 2017.

Djaffar Hasyim Muhammad, H. 2002. Penyediaan Air Bersih. Makassar: Jurusan Kesehatan Lingkungan Fakultas Kesehatan Masyarakat Universitas Hasanuddin.

Dwidjoseputro, D. 2010. Dasar-Dasar Mikrobiologi. Jakarta: Djambatan.

Effendi Hefni, 2003. Telaah Kualitas Air. Yogyakarta: Kanisius.

Entjang Indan. 2003. Mikrobiologi \& Parasitologi. Bandung: PT.Citra Aditya Bakti.

Lubis Ernani. 2012. Pelabuhan Perikanan. Bogor: PT.Penerbit IPB Press.

Sugiharto. 1983. Penyediaan Air Bersih Bagi Masyarakat.Jakarta: Proyek Pengembangan Pendidikan Dan Latihan Pegawai Departemen Kesehatan.

Supardi, dan Sukamto. 1999. Mikrobiologi Dalam Pengolahan Dan Keamanan Produk Pangan. (online). http://journal.uin-alauddin.ac.id/index.php/psb/article/view/2104 Bandung : Alumni Dapus Jurnal.

Suprihatin, dan Suparno Ono. 2013. Teknologi Proses Pengolahan Air. Bogor: PT.Penerbit IPB Press.

Sutrisno Totok, dan Suciastuti Eni. 2010. Teknologi Penyediaan Air Bersih. Jakarta: Rineka Cipta.

Suyono, dan Budiman. 2012. IImu Kesehatan Masyarakat. Jakarta: EGC.

Wahyuni Sahani, dkk. 2017. Panduan Penulisan Proposal Penelitian dan Skripsi. Makassar: Kementerian Kesehatan Republik Indonesia Politeknik Kesehatan Kemenkes Makassar Jurusan Kesehatan Lingkungan. 